\title{
Seroepidemiological study of maedi-visna in sheep in Ceara, Rio Grande do Norte, Paraíba, and Sergipe States ${ }^{1}$
}

\section{Estudo soroepidemiológico da maedi-visna em ovinos nos estados do Ceará, Rio Grande do Norte, Paraíba e Sergipe}

\author{
Samilly Mesquita Alves ${ }^{2 *}$; Maria Fátima da Silva Teixeira ${ }^{3}$; Raymundo Rizaldo \\ Pinheiro ${ }^{4}$; Francisco Selmo Fernandes Alves ${ }^{4}$; Ana Milena César Lima ${ }^{5}$; Daniele \\ Alves de Farias ${ }^{6}$; Vanderlan Warlington Souza dos Santos ${ }^{7}$; Dalva Alana Aragão de \\ Azevedo $^{8}$; Gabrielle Rosemblit Martins ${ }^{9}$; Tereza D Avila de Freitas Aguiar ${ }^{10}$
}

\begin{abstract}
The production performance of a livestock herd can be compromised by various diseases. In sheep, maedi-visna (MV) infections, which have a chronic nature, are caused by a virus (maedi-visna virus (MVV)) belonging to the genus Lentivirus of the Retroviridae family. The infection can cause significant economic losses and has considerable health impacts on sheep breeding in production systems. Due to the importance of this disease in sheep flocks, the objective was to conduct a serosurvey of MVV in the states of Ceará (CE), Rio Grande do Norte (RN), Paraíba (PB), and Sergipe (SE). A total of, 3332 serum samples were collected in the four states, 1011 in CE, 931 in RN, 459 in PB, and 931 in SE, with the number of samples proportional to the actual herd size of each state. The samples were analyzed using the agar gel microimmunodiffusion test (AGID). Reproducers were revaluated using western blotting (WB). In addition to this serological survey, we administered an investigative questionnaire to identify possible risk factors that facilitate the introduction and spread of diseases (location, category, sex, breed type, creation system, production, herd size, and association with goats). After analysis of the sera using the AGID test, there was zero prevalence. Revaluating breeders by WB revealed a 5.5\% prevalence of MV in the four states studied, with prevalences for the states of CE, RN, Paraiba, and SE of $2.3 \%(2 / 88), 10.4 \%(8 / 77), 3.6 \%(1 / 28)$, and $4.7 \%(2 / 42)$, respectively, corresponding to 13 breeders containing antibodies to the virus. These findings emphasized that the choice of diagnostic tests is extremely important for the early detection of seropositive animals and thus the prevention of the spread
\end{abstract}

Parte da Dissertação de Mestrado do primeiro autor,

2 Discente de Doutorado em Zootecnia, Universidade Federal do Ceará, UFC, Fortaleza, CE, Brasil. E-mail: samillealves@ hotmail.com

3 Prof ${ }^{a}$ Adjunta, Universidade Estadual do Ceará, UECE, Fortaleza, CE, Brasil. E-mail: mfteixeira@hotmail.com

4 Pesquisador A, Empresa Brasileira de Pesquisa Agropecuária, EMBRAPA CAPRINOS E OVINOS, Sobral, CE, Brasil. E-mail: rizaldo.pinheiro@embrapa.br; selmo.alves@embrapa.br

5 Discente de Doutorado em Ciência Animal, Universidade Federal do Piauí, UFPI, Teresina, PI, Brasil. E-mail: anamilenalima@ yahoo.com.br

6 Profa, Curso Técnico em Agropecuária, Instituto Centro de Ensino Tecnológico, CENTEC, Granja, CE, Brasil. E-mail: danieleafarias@hotmail.com

7 Zootecnista, Dr. em Ciência Animal, Universidade Federal Rural do Semi-Árido, UFERSA, Mossoró, RN, Brasil. E-mail: vanderlansouza@zootecnista.com.br

8 Discente de Doutorado em Ciências Veterinárias, Universidade Estadual do Ceará, UECE, Fortaleza, CE, Brasil. E-mail: dalvaazevedo@outlook.com

9 Médica Veterinária, Dr ${ }^{\mathrm{a}}$ em Ciências Veterinárias, UECE, Fortaleza, CE, Brasil. E-mail: rmgabrielle@hotmail.com

${ }^{10}$ Médica Veterinária, Pós-Doutora em Ciências Veterinárias, UECE, Fortaleza, CE, Brasil. E-mail:davilavet@gmail.com

* Author for correspondence

Received: Aug. 28, 2017 - Approved: July 19, 2018 
of the virus among herds in the region.

Key words: Disease. Sheep. Maedi-visna. Lentiviruses. Serology.

\section{Resumo}

O desempenho produtivo de um rebanho pode ser comprometido por diversas enfermidades. Em relação aos ovinos, à ocorrência da Maedi - Visna (MV) doença infecciosa, de caráter crônico, causada por um vírus (Maedi-Visna Vírus - MVV) pertencente ao gênero Lentivirus da família Retroviridae. A infecção pode causar importantes perdas econômicas e elevados impactos sanitários nos sistemas de produção da ovinocultura. Em virtude da importância desta enfermidade nos rebanhos ovinos, o objetivo do estudo foi realizar um levantamento soroepidemiológico do vírus da Maedi - Visna (MVV) nos estados do Ceará (CE), Rio Grande do Norte (RN), Paraíba (PB) e Sergipe (SE). Para tanto, foram coletadas 3332 amostras de sangue nos quatro estados, sendo 1011 do CE, 931 do RN, 459 da PB e 931 de SE, sendo este número de amostras proporcional ao rebanho efetivo de cada estado. As amostras foram analisadas utilizando o teste de microimunodifusão em gel de ágar (IDGA). Os reprodutores foram reavaliados pela técnica de Western Blot (WB). Associado a esse levantamento sorológico foi aplicado um questionário epidemiológico para identificar possíveis fatores de risco que podem facilitar a introdução e disseminação de enfermidades (localização, categoria, sexo, tipo racial, sistema de criação, produção, tamanho de rebanho e associação com caprinos). Após análise dos soros pelo teste de IDGA foi verificada uma soroprevalência nula nos rebanhos estudados. Os reprodutores reavaliados pelo WB apresentaram uma prevalência geral de 5,5\% da MV nos quatro estados estudados, sendo que os estados do Ceará, Rio Grande do Norte, Paraíba e Sergipe apresentaram, 2,3\% (2/88), 10,4\% $(8 / 77), 3,6 \%(1 / 28)$ e $4,7 \%(2 / 42)$ respectivamente, correspondendo a 13 reprodutores que apresentaram presença de anticorpos. Diante desses resultados, ressalta-se que a escolha dos testes diagnósticos é de extrema importância para que haja uma detecção precoce de animais soropositivos, e assim evitar a disseminação do vírus nos rebanhos da região.

Palavras-chave: Enfermidade. Ovinos. Maedi-visna. Lentivirus. Sorologia.

\section{Introduction}

Brazil has a total of 16,789,492 sheep, $60 \%$ of which are concentrated in the Northeast region of the country (IBGE, 2012). The states of Ceará (CE), Rio Grande do Norte (RN), Paraíba (PB), and Sergipe (SE) have $33 \%$ of the sheep herd of the Northeast, representing a total of 3,345,870 animals.

Despite these statistics, shortcomings in feeding and reproductive and health management, as well as the lack of zootechnical records and the late diagnosis of several pathologies, limit the productive performance of this species. Specially, in regions favoring disease dissemination, such as those caused by lentiviruses of small ruminants (LSR), there are two infections that are molecularly and biologically related: maedi-visna (MV) and caprine arthritis-encephalitis (CAE) (MOOJEN et al., 2001; SHAH et al., 2004).
MV is a compound name used to describe two infectious diseases in sheep that have a chronic and progressive behavior and share a common viral etiology: maedi, characterized by progressive interstitial pneumonia, and visna, characterized by leukoencephalomyelitis (CHRISTODOULOPOULOS, 2006).

The economic losses resulting from LSR are due to the reduction of the sheep's useful life, reduced weight gain, early disposal of high zootechnical value animals, and expenses associated with the adoption of control/eradication programs. In addition to the losses resulting from the disease itself, MV is listed as one of the compulsory notifiable diseases by the World Organization for Animal Health (OIE, 2017).

Lentiviruses are characterized by high genetic diversity due to high mutation rates (GJERSET et al., 2009). Their presence in herds even at low levels is 
cause for concern, as there is a tendency to intensify breeding, with the acquisition of animals to improve genetics and increase productivity. However, this practice is performed without adequate sanitary measures, which potentiates pathogen entry into pathogen-free regions (COSTA et al., 2007).

The diagnosis of MV is performed mainly using serological tests such as the agar gel microimmunodiffusion test (AGID), the indirect enzyme immunoassay (ELISA), and western blotting (WB). The AGID test is the most frequently used because of its high specificity and practicality, and it is recommended by the World Organization of Animal Health (OIE, 2017).

Due to the importance of this disease and considering the lack of information about it in some regions, an updated MV seroepidemiological survey is the first step in implementing control measures to prevent its spread, which can be followed by public policies for the sector. Therefore, this study aimed at evaluating the seroprevalence of sheep Maedivisna virus in the states of $\mathrm{CE}, \mathrm{RN}, \mathrm{PB}$, and SE.

\section{Material and Methods}

The study followed the ethical principles adopted by the National Council for the Control of Animal Experimentation - CONCEA (Law No. 11,794, October 8, 2008), and it received a favorable statement from the Ethics Commission on Animal Use of the Vale do Acaraú State University (CEUA/ UVA) under number 012.12.

\section{Study areas}

The study was conducted in four states of Northeast Brazil: CE, RN, PB, and SE, all located within a semiarid region. Three criteria were used for the selection of the study and sampling areas: they a) constituted a relevant mesoregion with an appropriate sheep stock density; B) housed an organizational productive arrangement that showed interest in participating in the project; and C) had an institutional structure sufficient to support the project to strengthen sheep productive chains.

The sheep populations of the states of $\mathrm{CE}, \mathrm{RN}$, $\mathrm{PB}$, and SE are 2,078,096, 558,563, 374,081, and 173,422 head, respectively (IBGE, 2012). These herds are composed of undefined race animals (URA), natives, and mestizos. The predominant production system is the extensive system with free grazing, and the sheep are raised with other species, mainly goats.

\section{Sampling and statistical design}

Non-probabilistic sampling was used to select the producers. This method was employed because there were no available lists of properties that would allow random sampling. Properties in the municipalities that were chosen had the highest representativeness of sheep breeding for the state or mesoregion, as described by associations of sheep farmers, agricultural secretaries, agricultural defense agencies, and technicians at rural extension companies.

The minimum number of samples to be tested $(n)$ was calculated statistically considering a minimum expected disease prevalence and considering the mean of the results of serological surveys conducted in other Brazilian states, with a confidence level of $95 \%$ and a sampling error of $3 \%$, according to Sampaio (2002). On each property, sampling was stratified according to the approximate Northeast herd composition (PINHEIRO et al., 2009), defined as $60 \%$ of matrices, $35 \%$ of young animals (between 6 and 12 months old), and all adult breeding animals. Samples from 20 animals were collected at each farm. The numbers of samples obtained in the states of CE, RN, PB, and SE are listed in Table 1.

In CE State, 1011 sheep blood samples were collected from 48 properties belonging to four mesoregions: the Metropolitan Region of Fortaleza, North, Northwest, and Backlands of CE. In total, 
10 municipalities of the state were sampled Independência, Parambu, Tauá, Quixeramobim, and (Pacajus, Granja, Santa Quitéria, Sobral, Canindé, Quixadá).

Table 1. Number of samples collected according to the mesoregion, municipality, and properties in the states of Ceará, Rio Grande do Norte, Paraíba, and Sergipe.

\begin{tabular}{|c|c|c|c|c|}
\hline State & Mesoregion & Municipality & Properties & Samples \\
\hline \multirow{10}{*}{ Ceará } & \multirow{3}{*}{ Northwest of Ceara } & Granja & 2 & 38 \\
\hline & & Santa Quitéria & 8 & 161 \\
\hline & & Sobral & 9 & 180 \\
\hline & North of Ceara & Canindé & 3 & 60 \\
\hline & Metropolitan Region of Fortaleza & Pacajus & 1 & 20 \\
\hline & \multirow{5}{*}{ Backlands of Ceara } & Independencia & 7 & 141 \\
\hline & & Parambu & 2 & 40 \\
\hline & & Taua & 5 & 100 \\
\hline & & Quixeramobim & 7 & 191 \\
\hline & & Quixada & 4 & 80 \\
\hline Subtotal & 4 & 10 & 48 & 1001 \\
\hline \multirow{7}{*}{$\begin{array}{l}\text { Rio Grande } \\
\text { do Norte }\end{array}$} & \multirow{4}{*}{ Central Potiguar } & Afonso Bezerra & 6 & 113 \\
\hline & & Angicos & 6 & 120 \\
\hline & & Lajes & 8 & 158 \\
\hline & & Pedro Avelino & 4 & 81 \\
\hline & \multirow{3}{*}{ West Potiguar } & Apodi & 13 & 259 \\
\hline & & Caraubas & 5 & 100 \\
\hline & & Mossoro & 5 & 100 \\
\hline Subtotal & 2 & 7 & 47 & 931 \\
\hline \multirow{8}{*}{ Paraíba } & \multirow{4}{*}{ Borborema } & Monteiro & 5 & 98 \\
\hline & & Sumé & 5 & 105 \\
\hline & & Prata & 1 & 20 \\
\hline & & São João do Cariri & 3 & 41 \\
\hline & \multirow{4}{*}{ Backlands of Paraiba } & Pombal & 2 & 40 \\
\hline & & Cacimba de Areia & 2 & 40 \\
\hline & & Quixaba & 3 & 55 \\
\hline & & Passagem & 3 & 60 \\
\hline Subtotal & 2 & 8 & 24 & 459 \\
\hline
\end{tabular}


continuation

\begin{tabular}{|c|c|c|c|c|}
\hline \multirow{8}{*}{ Sergipe } & \multirow{3}{*}{ Agreste of Sergipe } & Poço Verde & 8 & 170 \\
\hline & & Simão Dias & 3 & 52 \\
\hline & & Lagarto & 3 & 40 \\
\hline & \multirow{5}{*}{ Backlands of Sergipe } & Nossa Senhora da Glória & 6 & 110 \\
\hline & & Canindé de São Francisco & 6 & 100 \\
\hline & & Poço Redondo & 13 & 279 \\
\hline & & Gararu & 2 & 40 \\
\hline & & Tobias Barreto & 9 & 140 \\
\hline Subtotal & 2 & 8 & 50 & 931 \\
\hline Total & 10 & 33 & 169 & 3332 \\
\hline
\end{tabular}

In RN State, 931 sheep blood samples were collected from 47 properties belonging to the Central and West Potiguar mesoregions. Eight different municipalities were selected (Afonso Bezerra, Angicos, Lajes, Pedro Avelino, Apodi, Caraúbas, Upanema, and Mossoró).

In PB State, 459 blood samples were collected from 24 properties belonging to the Borborema and Backlands mesoregions of PB. Nine municipalities were selected (Monteiro, Sumé, Prata, São João do Cariri, Pombal, Cacimba de Areia, Quixaba, Camalau, and Passagem).

In SE State, 931 sheep samples were collected from 50 rural properties belonging to the Agreste and Backlands mesoregions of SE. Eight municipalities were sampled (Poço Verde, Lagarto, Tobias Barreto, Simão Dias, Canindé de São Francisco, Poço Redondo, Nossa Senhora da Glória, and Gararu).

\section{Blood collection}

Blood samples were collected by jugular venipuncture using vacuum tubes without an anticoagulant. Soon after collection, the tubes were centrifuged at $1,500 \times g$ to obtain the serum. The sera were placed in properly identified duplicate microtubes, which were then stored in a thermos container that was cooled and sent to Embrapa Goats and Sheep Clinical Pathology Laboratory, where they were stored at $-20{ }^{\circ} \mathrm{C}$ until the serological tests were performed.

\section{Epidemiological survey}

During the visit to each farm, a questionnaire was administered that addressed the general characteristics of the property, including possible infection risk factors, such as location, category, gender, breed type, breeding system, herd size, and association with goats.

\section{Diagnostic tests}

All the animals (matrices, young animals, and breeding herds) were evaluated using the AGID test, and for sheep breeders, WB was also used.

$A G I D$

For the detection of antibodies against MVV, the AGID test described by Gouveia et al. (2000) was used with a national antigen (Ag) produced in the Virology Laboratory of EMBRAPA Goats and Sheep, which was derived from cell cultures originating from sheep synovial membrane and inoculated with standard strain MVV-K1514 contains the gp135 (viral envelope) and structural 
protein p27 (capsid) proteins. The reading was performed after 48 and $72 \mathrm{~h}$ with indirect light and a dark background.

\section{$W B$}

Breeder sera $(n=235)$ were reassessed using WB, according to Rodrigues et al. (2014). The antigen proteins made with standard strain MVV-K1514 and purified by ultracentrifugation and a sucrose mattress were initially separated by sodium dodecyl sulfate polyacrylamide gel electrophoresis (SDS-PAGE) at a $4 \%$ concentration and $12.5 \%$ of separation. The separation was performed in a BIORAD model Power Pac HC, with initial conditions of $300 \mathrm{~W}, 1.00 \mathrm{~A}$, and $170 \mathrm{~V}$ for approximately $60 \mathrm{~min}$. Next, proteins were passively transferred contained to a nitrocellulose membrane (NM), which was blocked with phosphate buffered saline (PBS) (3.54 g Na $2 \mathrm{HPO}_{4}$ and $1.2 \mathrm{~g} \mathrm{NaH}_{2} \mathrm{PO}_{4}$ ) and $0.3 \%$ Tween with negative serum for $60 \mathrm{~min}$ and washed with $0.05 \%$ PBS-Tween solution three times (5 min each wash). Subsequently, the NM was cut into strips, properly identified, and divided into 5 $\mathrm{mL}$ test tubes with $1 \mathrm{X}$ PBS solution. Sera from the animals and the positive and negative controls were added to these tubes at a 1:50 dilution and incubated for $30 \mathrm{~min}$. Then, three washes were performed with PBS- $0.05 \%$ Tween (5 min each wash). The Sigma ${ }^{\circledR}$ conjugate (A 5420), peroxidase conjugated anti-goat IgG diluted in $1 \mathrm{X}$ PBS $(1: 15,000)$ was added and incubated for $60 \mathrm{~min}$. The strips were washed twice with $0.05 \%$ PBS-Tween and twice with $1 \mathrm{X}$ PBS (5 min each). The substrates 4-chloro-1-naphthol $\left(\right.$ Sigma $^{\circledR}, \quad$ C-6788) and 3,3'-diaminobenzidine (DAB) $\left(\right.$ Sigma $^{\circledR}$, D5637-5G) were added, followed by $30 \% \mathrm{H}_{2} \mathrm{O}_{2}$ (Fluko Analytical ${ }^{\circledR}$, 95313). Protein bands were developed in the dark for 30 to $60 \mathrm{~s}$, and the reaction was stopped with the addition of distilled water.

\section{Results and Discussion}

No anti-MVV antibodies were detected in the samples evaluated, using the AGID test, resulting in a zero prevalence for the disease in the studied regions. These data are attributed to the production characteristics of the sampled properties, such as an extensive breeding system and the predominant racial type (native, mixed, or undefined race animals), in which there was no virus entrance, which frequently occurs with the introduction of animals to improve exotic breeds (LARA et al., 2003).

Seroepidemiological studies conducted in the States of CE (PINHEIRO et al., 1996), SE (MELO et al., 2003), PB (GOUVEIA et al., 2003), Bahia (BARROS et al., 2010; SARDI et al., 2012), Amazonas (LIMA, 2011), and São Paulo (ROSA et al., 2009) also reported no prevalence of this virus in sheep. Results showing low prevalence values were also found in other Northeast states: $0.5 \%$ in CE (PRIMO et al., 2006), 0.5 and $0.3 \%$ in Bahia (SOUZA et al., 2007; MARTINEZ et al., 2010), and $0.1 \%$ in SE (MENDONÇA et al., 2013).

The herd breeding system has been reported to be a relevant risk factor for lentivirus infection (LEGINAGOIKOA et al., 2006). Among the evaluated states, the extensive regime was the predominant breeding system. The absence of disease observed in the studied regions may be due to this type of adopted management, where the animals do not remain clustered, which makes it difficult to transmit the disease.

Studies have shown that horizontal transmission is the most important route for the maintenance of the virus in sheep herds (BROUGHTONNEISWANGER et al., 2010), occurring more easily in situations of high population density due to permanent exposure to seropositive animals. Consequently, animals can come into contact with contaminated secretions (BLACKLAWS et al., 2004; BROUGHTON-NEISWANGER et al., 2010; 
VILLORIA et al., 2013) and become infected by inhaling aerosols or ingesting water containing viral particles (VILLORIA et al., 2013).

Thus, it is believed that in an intensive or semiintensive system, due to the close relationship among animals, the number of animals carrying the virus is much higher (ALMEIDA et al., 2003), and herds subjected to extensive breeding systems, although exposed to the virus by vertical transmission, can demonstrate low or no prevalence (LEGINAGOIKOA et al., 2006).

The LSR are characterized as causing infectious diseases that infect sheep at various stages of life, regardless of race, gender, and age. However, some studies have reported a higher incidence in exotic breeds of sheep such as Dorper, White Dorper, Texel, Ile de France, and mestizos (CASTRO; MELO, 2001; CASTRO, 2003). In this study, there was a predominance of native, mestizo, or undefined race among the extensively reared animals, characteristics that probably influenced the results.

In Pernambuco State, a serological survey was carried out on 25 Santa Inês sheep-producing properties, totaling 558 samples. The results showed positive MV serology in $1.07 \%$ of the sheep in $12 \%$ of the evaluated herds (COSTA et al., 2007). In Tocantins State, the prevalence of MV-positive sheep was $0.9 \%$ (8/838). Among the races, Santa Inês was the one with the highest percentage of seropositive animals, $1.17 \%$ (6/511), followed by undefined race animals at $0.6 \%(2 / 324)$ (MOURA SOBRINHO et al., 2008).

Important aspects that should be considered during the evaluation of these results are the sensitivity and specificity of the test used. The AGID screening test is recommended by the World Organization for Animal Health (OIE) and is widely used for diagnosis of LSR because of its practicality and low cost (OIE, 2017). It is considered to have good specificity and is technically simple and fast, but it may have reduced sensitivity for detecting antiLSR antibodies and may lead to underestimating the infection level of herds.

The absence of seropositive animals observed in this study may not reflect the actual LSR infection situation in sheep herds in the studied states. The infected animals may exhibit a late seroconversion, a characteristic commonly observed in some LSRinfected animals that may negatively affect the disease sensitivity of the AGID test. An alternative is the use of tests that have a higher sensitivity than the AGID test, such as WB, or direct diagnostic techniques, such as polymerase chain reaction (PCR) (KARANIKOLAOU et al., 2005).

Among the serological tests commonly used for the diagnosis of LSR, WB is the most sensitive because it has the capacity to detect antibodies at a dilution up to 128 times higher than the AGID test and 16 times higher than the indirect ELISA (PINHEIRO et al., 2012). Therefore, it is preferred for detecting low levels of antibodies.

Sheep breeders $(n=235)$ were reassessed using $\mathrm{WB}$, and a MV prevalence of $5.5 \%$ was found for the four states studied, and the states of CE, RN, PB, and SE showed prevalence rates of $2.3 \%$ (2/88), $10.4 \%$ $(8 / 77), 3.6 \%(1 / 28)$, and $4.7 \%$ (2/42), respectively, corresponding to 13 breeders containing antibodies. It is worth noting that the identification of only one serum-reactive animal with the diagnostic test characterizes the breeder as positive (Table 2). This result shows that the infection exists in the sheep herds of these states and that only WB, due to its higher sensitivity, could detect animals carrying anti-LSR antibodies. Similar data were reported by Magalhães (2012) in a sheep herd submitted to an LSR control program.

The presence of sheep lentivirus was verified in $8 \%$ of the studied properties, with rates of $2.6 \%$ $(1 / 39)$ in $\mathrm{CE}, 16.2 \%(7 / 43)$ in $\mathrm{RN}, 5 \%(1 / 20)$ in $\mathrm{PB}$, and $5.7 \%(2 / 35)$ in $\mathrm{SE}$ for 11 seropositive breeders (Table 3 ). It is worth noting that for goats, 
breeding animals may represent important sources of infection because the presence of the virus in the semen and sex organs has already been verified. Hence, a single breeder can be responsible for the contamination of a large number of animals, enabling the dissemination of the virus in the herd; thus, more rigid controls are necessary (PAULA, 2008; ANDRIOLI et al., 2006).
Lentiviruses are present in several Brazilian states (MARQUES, 2006; LOMBARDI et al., 2009; MAZZINGHY, 2013). Reports on lentiviruses in goats are more common in Brazil compared to those in sheep herds (OLIVEIRA et al., 2006; EMBRAPA, 2012). These data are a cause for concern because the virus is present in several Brazilian states and there is evidence of the cross-infection of sheep to goats and vice versa (SOUZA et al., 2012).

Table 2. Percentage of seropositive animals for the MVV western blotting in the states of Ceará, Rio Grande do Norte, Paraíba, and Sergipe.

\begin{tabular}{|c|c|c|c|c|c|c|}
\hline \multirow{2}{*}{ State } & \multirow{2}{*}{ Municipality } & \multirow{2}{*}{ Breeders } & \multicolumn{4}{|c|}{ RESULTS } \\
\hline & & & Negative & $\%$ & Positive & $\%$ \\
\hline \multirow{10}{*}{ Ceará } & Granja & 2 & 2 & 100 & 0 & 0.0 \\
\hline & Santa Quitéria & 13 & 12 & 92.3 & 1 & 7.7 \\
\hline & Sobral & 25 & 24 & 96.0 & 1 & 4.0 \\
\hline & Canindé & 3 & 3 & 100 & 0 & 0.0 \\
\hline & Pacajus & 2 & 2 & 100 & 0 & 0.0 \\
\hline & Independência & 13 & 13 & 100 & 0 & 0.0 \\
\hline & Parambu & 4 & 4 & 100 & 0 & 0.0 \\
\hline & Tauá & 9 & 9 & 100 & 0 & 0.0 \\
\hline & Quixadá & 7 & 7 & 100 & 0 & 0.0 \\
\hline & Quixeramobim & 10 & 10 & 100 & 0 & 0.0 \\
\hline Subtotal & 10 & 88 & 86 & 97.7 & 2 & 2.3 \\
\hline \multirow{7}{*}{$\begin{array}{l}\text { Rio Grande do } \\
\text { Norte }\end{array}$} & Afonso Bezerra & 9 & 5 & 55.6 & 4 & 44.4 \\
\hline & Angicos & 11 & 9 & 81.8 & 2 & 18.2 \\
\hline & Lages & 13 & 12 & 92.3 & 1 & 7.7 \\
\hline & Pedro Avelino & 8 & 8 & 100 & 0 & 0.0 \\
\hline & Apodi & 24 & 23 & 95.8 & 1 & 4.2 \\
\hline & Caraúbas & 7 & 7 & 100 & 0 & 0.0 \\
\hline & Mossoró & 5 & 5 & 100 & 0 & 0.0 \\
\hline Subtotal & 7 & 77 & 69 & 89.6 & 8 & 10.4 \\
\hline \multirow{8}{*}{ Paraíba } & Monteiro & 7 & 7 & 100 & 0 & 0.0 \\
\hline & Sumé & 3 & 3 & 100 & 0 & 0.0 \\
\hline & Prata & 1 & 1 & 100 & 0 & 0.0 \\
\hline & São João do Cariri & 4 & 4 & 100 & 0 & 0.0 \\
\hline & Pombal & 4 & 4 & 100 & 0 & 0.0 \\
\hline & Cacimba de Areia & 2 & 2 & 100 & 0 & 0.0 \\
\hline & Quixaba & 4 & 3 & 75.0 & 1 & 25.0 \\
\hline & Passagem & 3 & 3 & 100 & 0 & 0.0 \\
\hline Subtotal & 8 & 28 & 27 & 96.4 & 1 & 3.6 \\
\hline
\end{tabular}


continuation

\begin{tabular}{clccccc}
\hline \multirow{5}{*}{ Sergipe } & Poço Verde & 7 & 6 & 85.7 & 1 & 14.3 \\
\cline { 2 - 7 } & Simão Dias & 3 & 7 & 100 & 0 & 0.0 \\
\cline { 2 - 7 } & Lagarto & 2 & 2 & 100 & 0 & 0.0 \\
\cline { 2 - 7 } & Nossa Senhora da Glória & 7 & 6 & 85.7 & 1 & 14.3 \\
\cline { 2 - 7 } & Canindé de São Francisco & 4 & 4 & 100 & 0 & 0.0 \\
\cline { 2 - 7 } & Poço Redondo & 10 & 10 & 100 & 0 & 0.0 \\
\cline { 2 - 7 } & Gararu & 2 & 2 & 100 & 0 & 0.0 \\
\cline { 2 - 7 } & Tobias Barreto & $\mathbf{4 2}$ & $\mathbf{4 0}$ & $\mathbf{9 5 . 3}$ & $\mathbf{2}$ & $\mathbf{4 . 7}$ \\
\hline Subtotal & $\mathbf{8}$ & $\mathbf{2 3 5}$ & $\mathbf{2 2}$ & $\mathbf{9 4 . 5}$ & $\mathbf{1 3}$ & $\mathbf{5 . 5}$ \\
\hline Total & $\mathbf{3 3}$ & & &
\end{tabular}

Table 3. Percentage of properties with MVV seropositive animals western blotting in the states of Ceará, Rio Grande do Norte, Paraíba, and Sergipe.

\begin{tabular}{lccccc}
\hline \multirow{2}{*}{ State } & Properties & \multicolumn{4}{c}{ RESULTS } \\
\cline { 3 - 6 } & & Negative & $\%$ & Positive & $\%$ \\
\hline Ceará & 39 & 38 & 97.4 & 1 & 2.6 \\
Rio Grande do Norte & 43 & 36 & 83.8 & 7 & 16.2 \\
Paraíba & 20 & 19 & 95.0 & 1 & 5 \\
Sergipe & 35 & 33 & 94.3 & 2 & 5.7 \\
\hline Total & $\mathbf{1 3 7}$ & $\mathbf{1 2 6}$ & $\mathbf{9 2 . 0}$ & $\mathbf{1 1}$ & $\mathbf{8}$ \\
\hline
\end{tabular}

\section{Conclusions}

The AGID technique did not detect anti-MVV antibodies in the animals of the evaluated herds. LSR were present at a low prevalence on the evaluated sheep breeding properties in the states of $\mathrm{CE}, \mathrm{RN}, \mathrm{PB}$, and $\mathrm{SE}$, and $\mathrm{WB}$ was more sensitive than the AGID test for MV diagnosis.

Due to the importance of sheep farming for the studied states, the choice of diagnostic tests is of extreme importance for the early detection of seropositive animals, which can help prevent the spread of the virus among the herds of the region.

\section{Acknowledgements}

We thank the Brazilian Agricultural Research Agency (EMBRAPA) - National Center for Goats and Sheep Research and the National Council for
Scientific and Technological Development (CNPq) for funding the research through $\mathrm{CNPq} / \mathrm{MAPA} / \mathrm{SDA}$ No 64/2008 and process No 578438/2008-9 and the Cearense Foundation for the Support of Scientific and Technological Development (FUNCAP) for providing a research grant.

\section{References}

ALMEIDA, N. C.; TEIXEIRA, M. F. S.; FERREIRA, R. C. S.; CALLADO, A. K. C.; FROTA, M. N. L.; MELO, A. C. M.; APRIGIO, C. J. L. Detecção de ovinos soropositivos para Maedi/Visna destinados ao abate na região metropolitana de Fortaleza. Veterinária Notícias, Uberlândia, v. 9, n. 1, p. 59-63, 2003.

ANDRIOLI, A.; GOUVEIA, A. M. G.; MARTINS, A. S.; PINHEIRO, R. R.; SANTOS, D. O. Fatores de risco na transmissão do lentivírus caprino pelo sêmen. Pesquisa Agropecuária Brasileira, Brasília, v. 41, n. 8, p. 13131319, 2006. 
BARROS, I. N.; SILVA, N. S.; ALMEIDA, M. G. A. R.; ANUNCIAÇÃO, A. V.; LABORDA, S. S.; RAMALHO, E. J.; OLIVEIRA, E. M. D. Detection of antibodies to Visna/Maedi in sheep from Recôncavo Baiano. Revista Ciências Agrárias, Belém, v. 53, n. 2, p. 206-211, 2010.

BLACKLAWS, B. A.; BERRIATUA, E.; TORSTEINSDOTTIR, S.; WATT, N. J.; ANDRES, D. de; KLEIN, D.; HARKISS, G. D. Transmission of small ruminant lentiviruses. Veterinary Microbiology, Amsterdam, v. 101, n. 3, p. 199-208, 2004.

BROUGHTON-NEISWANGER, L. E.; WHITE, S. N.; KNOWLES, D. P.; MOUSEL, M. R.; LEWIS, G. S.; HERNDON, D. R.; HERRMANN-HOESING, L. M. Non-maternal transmission is the major mode of ovine lentivírus transmission in a ewe flock: a molecular epidemiology study. Infection, Genetics and Evolution, Irvine, v. 10, n. 7, p. 998-1007, 2010.

CASTRO, R. S. Lentivirose caprina e ovina. In: SIMPÓSIO INTERNACIONAL SOBRE CAPRINOS E OVINOS DE CORTE, 2003, João Pessoa. Anais... João Pessoa: EMEPA-PB, 2003. p. 133-140.

CASTRO, R. S.; MELO, L. E. H. CAEV e MaediVisna: importância na saúde e produtividade de caprinos e ovinos e a necessidade de seu controle no nordeste brasileiro. Ciência Veterinária nos Trópicos, Recife, v. 4, n. 2-3, p. 315-320, 2001.

CHRISTODOUlOPOUlOS, G. Maedi-Visna: Clinical review and short reference on the disease status in Mediterranean countries. Small Ruminant Research, Amsterdam, v. 62, n. 1-2, p. 47-53, 2006.

COSTA, L. S. P.; LIMA, P. P.; CALLADO, A. K. C.; NASCIMENTO, S. A.; CASTRO, R. S. Lentivírus de pequenos ruminantes em ovinos Santa Inês: isolamento, identificação pela PCR e inquérito sorológico no estado de Pernambuco. Arquivos do Instituto Biológico, São Paulo, v. 74, n. 1, p. 11-16, 2007.

EMPRESA BRASILEIRA DE PESQUISA AGROPECUÁRIA - EMBRAPA. Lentivirose de pequenos ruminantes e brucelose ovina no Brasil. Sobral: Embrapa Caprinos e Ovinos, 2012. 11 p.

GJERSET, B.; RIMSTAD, E.; TEIGE, J.; SOETAERT, K.; JONASSEN, C. M. Impact of natural sheep-goat transmission on detection and control of small ruminant lentivirus group C infections. Veterinary Microbiology, Amsterdam, v. 135, n. 3-4, p. 231-238, 2009.

GOUVEIA, A. M. G.; LIMA, F. A.; SOUSA, G. J. G.; LOBATO, Z. I. P.; SILVA, A. H.; SILVA, M. A. V.; CYPRESTE, B. M. Frequência sorológica de Maedi-Visna, Língua Azul em ovinos, em propriedades e matadouro da Paraíba. In: CONGRESSO
LATINOAMERICANO, CONGRESSO BRASILEIRO, CONGRESSO NORDESTINO DE BUIATRIA, 11., 5., 3., 2003, Salvador. Anais... Salvador: SBB, 2003, 52 p.

GOUVEIA, A. M. G.; MELO, L. M.; PIRES, L. L.; PINHEIRO, R. R. Microimunodifusão em gel de ágar para o diagnóstico sorológico de infecção por Lentivírus de pequenos ruminantes. In: CONGRESSO BRASILEIRO DE MEDICINA VETERINÁRIA, 27., 2000, Águas de Lindóia. Anais... Águas de Lindóia: [s. n.], 2000, 33 p.

INSTITUTO BRASILEIRO DE GEOGRAFIA E ESTATÍSTICA - IBGE. Pesquisa Pecuária Municipal 2012. Disponível em: <http://www.ibge.br/sidra>. Acesso em: 2 maio 2015.

KARANIKOLAOU, K.; ANGELOPOULOU, K.; PAPANASTASOPOULOU, M.; KOUMPATIARTOPIOU, M.; PAPADOPOULOS, O.; KOPTOPOULOS, G. Detection of small ruminant lentiviruses by PCR and serology tests in field samples of animals from Greece. Small Ruminant Research, Amsterdam, v. 58, n. 2, p. 181-187, 2005.

LARA, M. C. C. S. H.; BIRGEL JÚNIOR, E. H.; FERNANDES, M. A.; BIRGEL, E. H. Infecção experimental do vírus da artrite-encefalite dos caprinos em cabritos. Arquivos do Instituto Biológico, São Paulo, v. 70, n. 1, p. 51-54, 2003.

LEGINAGOIKOA, I.; JUSTE, R. A.; BARANDIKA, J.; AMORENA, B.; DE ANDRES, D.; LUJAN, L.; BADIOLA, J.; BERRIATUA, E. Extensive rearing hinders maedi-visna virus (MVV) infection in sheep. Veterinary Research, Londres, v. 37, n. 6, p. 767-778, 2006.

LIMA, N. S. Incidência de maedi-visna na população de ovinos (Ovis aries) em propriedades rurais da região metropolitana de Manaus- AM. 2011. Dissertação (Medicina Veterinária) - Escola Superior Batista do Amazonas, Manaus.

LOMBARDI, A. L.; NOGUEIRA, A. H. C.; FERES, F. C.; PAULO, H. P.; CASTRO, R. S.; FEITOSA, F. L. F.; CADIOLI, F. A.; PEIRÓ, J. R.; PERRI, S. H. V.; LIMA, V. F. M.; MENDES, L. C. N. Soroprevalência de MaediVisna em ovinos na região de Araçatuba, SP. Arquivo Brasileiro de Medicina Veterinária e Zootecnia, Belo Horizonte, v. 61, n. 6, p. 1434-1437, 2009.

MAGAlHÃES, D. C. T. Avaliação de um programa de controle para lentivirus de pequenos ruminantes em rebanho ovino criado extensivamente. 2012. Dissertação (Mestrado em Zootecnia) - Universidade Estadual Vale do Acaraú, Sobral.

MARQUES, A. P. R. Caracterização soroepidemiológica da infecção por vírus Maedi-Visna e Brucella ovis em 
ovinos no estado de Minas Gerais. 2006. Dissertação (Mestrado em Medicina Veterinária) - Universidade Federal de Minas Gerais, Belo Horizonte.

MARTINEZ, P. M.; COSTA, J. N.; SOUZA, T. S.; COSTA NETO, A. O.; PINHEIRO, R. R. Sistemas de criação de ovinos e ocorrência de anticorpos contra o vírus da Maedi-Visna na Microrregião de Juazeiro, BA. Revista Brasileira de Saúde e Produção Animal, Salvador, v. 11, n. 2, p. 342-353, 2010.

MAZZINGHY, C. L. Soropositividade para Maedi-Visna em ovinos. 2013. Dissertação (Mestrado em Ciência Animal Tropical) - Universidade Federal do Tocantins, Araguaína.

MELO, C. B.; CASTRO, R. S.; OLIVEIRA, A. A.; FONTES, L. B.; CALLADO, A. K. C.; NASCIMENTO, S. A. Estudo preliminar sobre a infecção por lentivírus de pequenos ruminantes em ovinos e caprinos em Sergipe. In: CONGRESSO BRASILEIRO DE BUIATRIA, 5., 2003, Salvador. Anais... Salvador: Sociedade Brasileira de Buiatria, 2003. p. 47-48.

MENDONÇA, C. E. D.; BARROS, S. L. B.; MENDONÇA, M. A. D.; GUIMARÃES, V. A. A.; PINHEIRO, R. R. Ocorrência de anticorpos contra o vírus Maedi-Visna em ovinos Santa Inês, no estado de Sergipe, Brasil. Arquivos Instituto Biológico, São Paulo, v. 80, n. 3, p. 346-351, 2013.

MOOJEN, V. Maedi-Visna dos ovinos. In: RIETCORREA, F.; SCHILD, A. L.; MENDEZ, M. D. C.; LEMOS, R. A. A. Doenças de ruminantes e equinos. São Paulo: Varela, 2001. v. 1, p. 138-144.

MOURA SOBRINHO, P. A.; FERNANDES, C. H. C.; RAMOS, T. R. R.; CAMPOS, A. C.; COSTA, L. M.; CASTRO, R. S. Prevalência e fatores associados à infecção por lentivírus de pequenos ruminantes em ovinos no Estado do Tocantins. Ciência Veterinária nos trópicos, Recife, v. 11, n. 2-3, p. 65-72, 2008.

OLIVEIRA, B. F. L.; BERGAMASCHI, K. B.; CRUZ, M. H. C.; SANTOS, D. D.; CRUZ, A. D.; CRUZ, J. F. Prevalência de lentiviroses em rebanhos caprinos e ovinos na região Sudoeste da Bahia. In: SEMINÁRIO DE INICIAÇÃO CIENTÍFICA DA UNIVERSIDADE ESTADUAL DE SANTA CRUZ - UESC, 12., 2006, Ilhéus. Anais.... Ilhéus: UESC, 2006. p. 134-135.

ORGANIZAÇÃO DE SAÚDE ANIMAL - OIE. Arttritis/ encefalitis caprina y Maedi-Visna. Manual de la OIE sobre animales terrestres. 2017. Disponible en: $<\mathrm{http}: / /$ web.oie.int/esp/normes/mmanual/pdf_es_2017/2.07.03$04 . \% 20$ Artritis-Encefalitis $\% 20$ caprina $\% 20 \mathrm{y} \% 20$ Maedi\%20Visna.pdf $>$. Acesso em: 10 jun. 2018.
PAULA, N. R. O. Parâmetros clínicos, hematológicos, sorológicos e reprodutivos em reprodutores natural e experimentalmente infectados com CAEV. 2008. Tese (Doutorado em Ciência Animal) - Universidade Estadual do Ceará, Fortaleza.

PINHEIRO, O. R.; XIMENES, L. J. F.; PINHEIRO, A. A.; TEIXEIRO, M. F. S. As ações do Banco do Nordeste do Brasil em $p$ \& $d$ na arte da pecuária de caprinos e ovinos no nordeste brasileiro. Fortaleza: Banco do Nordeste do Brasil, 2009. 436 p.

PINHEIRO, R. R.; ALVES, F. S. F.; SANTA ROSA, J.; GOUVEIA, A. M. G. Levantamento sorológico em ovinos para diagnóstico da Maedi-Visna em SobralCeará. In: CONGRESSO BRASILEIRO DE MEDICINA VETERINÁRIA, 24., 1996, Goiânia. Anais... Goiânia: SOGOVE, 1996. v. 362.

PINHEIRO, R. R.; ANDRIOLI, A.; SIDER, L. H.; SANTIAGO, L. B.; OLIVEIRA, E. L.; SOUSA, A. L. M.; ALVES, F. S. F.; CRUZ, J. C. M. Lentiviroses em pequenos ruminantes: principais métodos de diagnóstico. Sobral: EMBRAPA Caprinos e Ovinos. 2012. 42 p. (Documentos, 107).

PRIMO, T. S.; FARIAS, D. A.; ALVES, F. S. F.; OLIVEIRA, A. A. F.; ARAGÃO, M. A. C.; PINHEIRO, R. R. Enquete soroepidemiológica da Maedi Visna no estado do Ceará. In: SEMANA DA CAPRINOCULTURA E OVINOCULTURA BRASILEIRA, 5., 2006, Campo Grande. Anais... Campo Grande: EMBRAPA Gado de Cote; EMBRAPA Caprinos, 2006. p. 1-3.

RODRIGUES, A. S.; BRITO, R. L. L.; PINHEIRO, R. R.; DIAS, R. P.; ALVES, S. M.; SOUZA, T. S.; SOUZA, K. C.; AZEVEDO, D. A. A.; ANDRIOLI, A.; MAgalhãES, D. C. T.; TEIXEIRA, M. F. S. Padronização do ELISA indireto e Western Blot para o diagnóstico da artrite-encefalite caprina. Arquivo Brasileiro de Medicina Veterinária e Zootecnia, Belo Horizonte, v. 66, n. 2, p. 417-424, 2014.

ROSA, E. P.; AMORIM, R. M.; FERREIRA, D. O. L.; CHIACCHIO, S. B.; MODOLO, J. R. Soroprevalência da pneumonia progressiva ovina (Maedi-Visna) na região de Botucatu, SP. Ciência Animal Brasileira, Goiania, v. 10, n. 3, p. 847-852, 2009.

SAMPAIO, I. B. M. Estatística aplicada à experimentação animal. Belo Horizonte: Fundação de Ensino e Pesquisa em Medicina Veterinária e Zootecnia, 2002. 265 p.

SARDI, S. I.; TORRES, J. A.; BRANDÃO, C. F. L.; TIGRE, D. M.; CAMPOS, G. S. Early detection of goats infected with lentivirus small ruminant virus by ELISA assay. Revista de Ciências Médicas e Biológicas, Salvador, v. 11, n. 1, p. 35-40, 2012. 
SHAH, C.; BONI, J.; HUDER, J. B.; VOGT, H. R.; MÜHLHERR, J.; ZANONI, R.; MISEREZ, R.; LUTZ, H.; SCÜPBACH, J. Phylogenetic analysis and reclassification of caprine and ovine lentiviruses based on 104 new isolates: evidence for regular sheep-togoat transmission and worldwide propagation through livestock trade. Virology, Washington, v. 319, n. 1, p. 1226, 2004.

SOUZA, T. S.; COSTA, J. N.; MARTINEZ, P. M.; PINHEIRO, R. R. Estudo. Estudo sorológico da MaediVisna pelo método da imunodifusão em gel de ágar em rebanhos ovinos de Juazeiro, Bahia, Brasil. Revista Brasileira de Saúde e Produção Animal, Salvador, v. 8, n. 4, p. 276-282, 2007.
SOUZA, T. S.; PINHEIRO, R. R.; LIMA, C. C.; COSTA, J. N. Transmissão interespécie dos Lentivírus de pequenos ruminantes: revisão e desafios. Acta Veterinária Brasílica, Mossoró, v. 6, n. 1, p. 23-34, 2012.

VILLORIA, M.; LEGINAGOIKOA, I.; LUJÁN, L.; PÉREZ, M.; SALAZAR, E.; BERRIATUA, E.; JUSTE, R. A.; MINGUIJÓN, E. Detection of small ruminant Lentivirus in environmental samples of air and water. Small Ruminant Research, Amsterdam, v. 110, n. 2-3, p. 155-160, 2013. 